Maciej Lechowicz

\title{
LOCATION OF CAPITALS OF THE WORLD AND THE BOUNDARIES OF VEGETATION ZONES
}

Assuming the possibility of existence of an ideal location for a capital, one should consider its disposition with respect to the area of a given country. Theoretically, capitals ought to be located in the centre of the country, so as to make the accessibility of the capital city equally facile for the population of the whole country, to ensure that the capital really unites the whole state. A capital city located in the centre of the country is theoretically less prone to the threat of invasion. Economic factors introduce an important modification to the assumptions of an ideal location of the capital. The basis for the economic factors is often to a greater or lesser degree constituted by the natural conditions.

When observing the present distribution of the capitals of the world one should pay attention to the fact that harbour towns and towns located at the borders of physico-geographical zones constitute the dominating group among the capitals of the world (Janiszewski, 1982 and 1983). The question of capitals being seaports and located over the rivers was a subject of numerous reports (Staszewski, 1957; Zierhoffer, 1959; Beaujeu-Garnier, Chabot, 1971; Wrzosek, 1976). The influence of surface relief and of the physico-geographical boundaries on the location of capitals of the world was studied by Janiszewski $(1982,1983)$. His analyses referred to the influence exerted by the proximity to the sea, the role of large-scale relief forms (plains, uplands and bowls, mountains, passes), and of the physiographic boundaries in the location of capitals. In the respective reports the physiographical boundaries were understood as geomorphological boundaries, and so the question of their complexity was treated marginally.

Can the boundaries of vegetation formations have any significance for the location of capitals of the countries? It must be stated at the outset that to assign a too great weight to these boundaries seems to be a mistake. The role of interface, played by a boundary, where a variety of possibilities and attractions are offered, differs considerably, depending on whether the town (capital) was established spontaneously, i.e. its location and development were linked with economy and the way of living on a given area, or whether it was administratively imposed (the colonial period, the tendency of centralising the capital). 


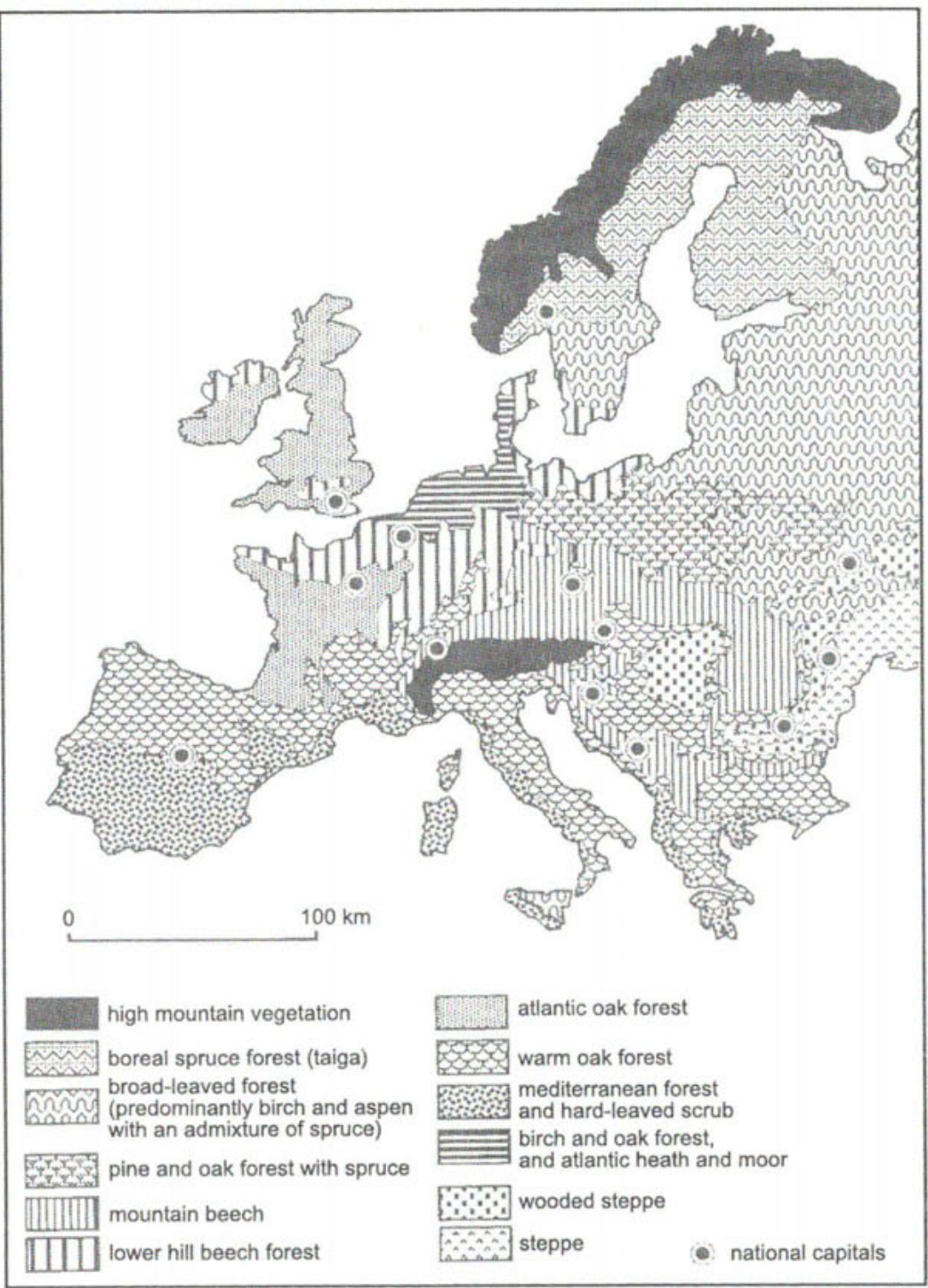

Fig. 1. Plant formations and location of selected capitals of European countries. According to Pergamon World Atlas (1968).

The question of influence exerted by the boundaries between vegetation formations on the location of capitals is insofar more complicated that, for instance, in case of an a-zonal vegetation it is hard to decide whether the development of a town, having become the capital, was more influenced by the location at the feet of a mountain range or by the location between often very different vegetation floors. In the situation of just such locations of 
towns, the rivers flowing from mountains gain special significance. The submountainous towns usually lie at the mouths of the mountain rivers, since this facilitates the penetration of the mountain regions, the river valleys opening up the way to these regions (the classical cases for such towns are Rome and Bonn). There are much less reservations when we consider the zone boundaries of the particular vegetation formations. It would be extremely difficult to find an instance of a town that was established solely because it is located on the boundary of vegetation zones. In many cases, though, it can be expected that the boundaries of the vegetation zones were one of the more important causes for a concrete location of the capital.

Out of the numerous advantages resulting from the location on the boundaries of plant formations these ones come to the forefront, which are connected with the economic factors. In the poorly developed countries, where the economy is primarily based upon agriculture, the differing environments of the two zones constitute a direct attraction. A part of the society of such countries lives a nomadic life, moving from one vegetation-and-climate zone to another, depending upon the climatic conditions, and seasons of the year. Such phenomena can be encountered in Central Asia or in Western Africa. Location on the border allows the capital to better play the role of the trade, administrative, and service centre of the country. In the economically better developed countries the situation is different, though the fundamental reasons behind the development of very old capitals are similar as in the developing countries. A different nature of the two vegetation formations does not determine directly the human fate. The differentiation of the environment, which appears along the borders, offers, on the other hand, the possibility of conducting various types of economic activity within the direct hinterland of the city. Location at the border of a steppe and a forest makes it possible, on the one hand, to develop agriculture, and, on the other - to develop industry (e.g. wood industry) or the tourist-and-health-resort activities. An instance of a capital taking advantage of such a location is Bucharest. On the one side there is the fertile Danubian plain and on the other - the relative proximity of the forested slopes of the Carpathian Mts, being nowadays the place of recreation for many inhabitants of the capital, while in older times - the area of gathering of mushrooms and berries, as well as of tree felling. Similar phenomena can be observed on the boundaries of two forest zones, where one of them, usually more fertile of the two, was transformed centuries ago into agricultural land. This is a frequent case in Europe, where the urban network is one of the oldest and best developed in the world. An instance of such a town is provided by Vienna. To the west of the city a range of hills - the Vienna Wood - is strongly forested and constitutes a popular tourist and recreational area of the Viennese. To the east of the city, on the other hand, a wide plain of agricultural land - the Moravian Field. The latter is the potential area of appearance of oak forests (as the more fertile habitats than those where these forests remained until today), which were so long ago 
cleared and turned into fields that the whole area is nowadays associated solely with farming. The situation with Prague is similar. Very much the same tendencies are observed at the border of the same vegetation zones. To the south and east of the capital the dispersed forest complexes border upon the capital, while on the north-western side there is a wide cultivated area, having replaced the stenothermal oak woods.

When we take a look at some selected capitals (Table 1) we should pay attention to the character of the vegetation border, close to which these towns are located. The majority of these borders will have a gradual character, there will be a gradual disappearance of the elements belonging to one of the zones and the appearance of the components of the other. Yet, the weight of these borders will be different, depending upon the degree of difference between the areas separated by them. In the listing of the capitals the groups were formed starting from the fine borders, separating the areas relatively similar, like two forest zones, through the borders dividing areas differing in a more clear manner, like a forest zone and a transitory zone (say - a wooded steppe), and ending with the borders which separate two distinctly different zones, like forest and steppe.

A large subgroup of towns located on the fine borders is constituted by those, which lie on the borders between two forest zones, this being the case of Vienna, Brussels, or Bern. In Europe this is most often the boundary between the oak woods occupying the areas of lower altitudes and the beech woods, growing higher. Both of these formations are economically highly valued. They are easily accessible, and all the species which are encountered there, can be used to produce cellulose. Among thirteen towns from Europe as many as seven are located on the borders of the zonal and a-zonal vegetation, being situated at the feet of mountains or uplands, or in the valleys. Bern was established in a bend of the Aare river, at the border of Alpine foothills, overgrown with the mountain spruce forest, and the Swiss Upland, with a more fertile environment of the $\mathrm{m}$ woods. Brussels, located at the border of the foreland of the Ardennes, lies at the same time at the border of the beech forests of foothills and the sparse oak forests with an admixture of birch, as well as heather and moor lands. Madrid, situated on the Castilian Plateau, close to the mountain passes, became the transport node located at the border of two different formations - the fertile areas occupied in ancient times by oak woods, and the more dry hard leaved forests. It was an attractive location between the fertile areas (oak woods) and the ones harder to develop, but providing valuable products (olive oil, citrus fruits, grapes). London and Paris are located on the border separating the humid Atlantic oak woods and the beech forests, occupying less fertile habitats. Prague, Sarajevo, Vienna, and Zagreb developed under the slopes of the mountains or uplands, at the border of the mountain beech forests and the stenothermal oak woods. The habitats of the fertile oak woods were mostly turned into agricultural land and play an important role in the direct food supply for the capitals. The mountain beech woods partly persisted. They 
Capitals at the borders of vegetation zones

\begin{tabular}{|c|c|c|}
\hline Capital & Country & $\begin{array}{l}\text { Vegetation zones on whose border the capital } \\
\text { is located }\end{array}$ \\
\hline \multicolumn{3}{|c|}{ Fine borders (small differences between the neighbouring plant formations) } \\
\hline Bamako & Mali & Humid (woody) savannah/dry savannah \\
\hline Bangkok & Thailand & Dry tropical forest/tropical rain forest/monsoon forest \\
\hline Bern & Switzerland & Mountain spruce forest/mountain beech forest \\
\hline Brussels & Belgium & Beech forests/Oak and birch forests and heather land \\
\hline Gaborone & Botswana & Dry savannah/thorny savannah \\
\hline London & United Kingdom & Atlantic oak forests/beech forest \\
\hline Madrid & Spain & $\begin{array}{l}\text { Stenothermal oak woods/mediterranean forest and } \\
\text { hard leaved scrub }\end{array}$ \\
\hline Ndjamena & Chad & Dry savannah/very dry savannah \\
\hline Niamey & Niger & Dry savannah/very dry savannah \\
\hline Oslo & Norway & Birch and aspen forest with spruce/spruce and fir taiga \\
\hline Paris & France & Atlantic oak forests/beech woods \\
\hline Prague & Czech Rep. & Stenothermal oak woods/mountain beech forest \\
\hline Sarajevo & $\begin{array}{l}\text { Bosna \& } \\
\text { Herzegovina }\end{array}$ & Stenothermal oak woods/mountain beech forest \\
\hline Washington D.C. & USA & Mixed and evergreen coniferous forest/deciduous forest \\
\hline Vienna & Austria & Stenothermal oak woods/mountain beech forest \\
\hline Zagreb & Croatia & Stenothermal oak woods/mountain beech forest \\
\hline \multicolumn{3}{|r|}{ Intermediate borders } \\
\hline Brazzaville & Congo & Tropical rain forest/tropical rain forest with savannah \\
\hline Bucharest & Romania & Stenothermal oak woods/wooded steppe \\
\hline Kiev & Ukraine & Wooded steppe/birch and aspen forest with spruce \\
\hline Kinshasa & Dem. Rep. Congo & Tropical rain forest/tropical rain forest with savannah \\
\hline Pretoria & Rep. of South & High grass steppe/dry savannah \\
\hline Ulan Bator & Mongolia & Low grass steppe/wooded steppe \\
\hline \multicolumn{3}{|c|}{$\begin{array}{c}\text { General borders } \\
\text { (significant differences between the neighbouring vegetation formations) }\end{array}$} \\
\hline Amman & Jordan & Hard leaved forests and scrub/semi-desert \\
\hline Ankara & Turkey & $\begin{array}{l}\text { Mountain low grass steppe/dry hard leaved forest and } \\
\text { scrub }\end{array}$ \\
\hline Antananarivo & Madagascar & Tropical rain forest/dry savannah \\
\hline Astana & Kazakhstan & Low grass steppe/semi-desert \\
\hline Ashkhabad & Turkmenista & Mountain low grass steppe/desert \\
\hline Bishkek & Kirghistan & Mountain low grass steppe/semi-desert \\
\hline Canberra & Australia & Hard leaved forest/savannah \\
\hline Damascus & Syria & Hard leaved forests and scrub/semi-desert \\
\hline Dodoma & Tanzania & $\begin{array}{l}\text { Subtropical forest (shedding leaves in dry season)/ } \\
\text { very dry savannah }\end{array}$ \\
\hline Dushanbe & Tajikistan & Mountain low grass steppe/semi-desert \\
\hline Kishyniev & Moldova & Birch and aspen forest with spruce/meadow (flower) steppe \\
\hline Luanda & Angola & Tropical rain forest/dry savannah \\
\hline Tashkent & Uzbekistan & Mountain low grass steppe/semi-desert \\
\hline Teheran & Iran & Mountain low grass steppe/semi-desert \\
\hline
\end{tabular}


functioned - and still function - as the gathering areas (like, anyway, the oak woods centuries ago), but they also are the recreational and leisure areas. Location of Oslo is somewhat different: at the border of the different forest complexes - coniferous (taiga) and deciduous. Similarly, outside of Europe - Washington, D.C. - located at the border of Appalachian Mts and the Atlantic Plain, is also situated on the boundary of two differing forest complexes, the fertile areas of deciduous forests and the poorer habitats of the mixed and coniferous forests. Bangkok is located at the border of as many as three forest formations: the tropical rain forest, the transitorily dry monsoon forest, and the dry tropical forest.

Another subgroup is constituted by the African capitals located at the border of two types of savannahs: dry and very dry. Within both these formations extensive animal husbandry may virtually exclusively be developed. Gaborone took shape at the edge of the Kalahari Low, at the border of vegetation zones, as the trade centre for the cattle raising region. Ndjamena is a river port on the Shari river close to the mouth of Logone to the south of Chad lake. The city is the transport node of the country. While in the case of Gaborone it is difficult to find more factors other than the border between the vegetation zones, which could have influence on the location of this particular capital, in case of Ndjamena the question is more complex, the vegetation border cannot be attributed any big importance. The third town located at the same border is Niamey, on the river Niger. The capital of Mali, Bamako, is also located on the border of the two varieties of savannahs - dry and humid. The riverside location (Niger) plays in the case of Bamako an important role. Similarly as the remaining capitals of the zone of savannahs, Bamako developed on the areas more humid than the rest of the country.

The above examples cannot be applied to the location of Pretoria, opening the second group of towns situated at the vegetation borders, which are intermediate between the fine and the general ones. The town is located at the border between the Kalahari Low, at the limits of fertile steppes and infertile dry savannah. The steppes allowed for the development of the cereals' cultivation area, which is the largest in Africa, neighbouring upon the savannahs with their traditional farming. In this case, as well, the border of vegetation zones had a significant impact upon location. Similarly, more distinct differences can be observed on the border between the forest formations and the transitory ones - the wooded steppe. Bucharest was established on the Wallachian Plain, at a distance from the boggy valley of Danube, on its confluent, at the junction of wooded steppes and stenothermal oak woods. Kiev, located in its major part on the high right-hand bank of Dneper river, was during an important period of its existence very deeply connected with two interpenetrating cultures - the nomadic one, originating from the steppes, and the settled - from the forest zone. Location at the border between the steppe and the forest was the source for the flourishing of Kiev (based not only on the far trade, but also on the close one). 
Although Brazzaville is a typical riverside town, the neighbourhood of the equatorial forest with the areas partly occupied by humid savannah is certainly attractive. The greater natural plant productivity and the specie variety in the border zone of the forest and the savannah ensures bigger possibilities of finding plants for food, which is most presumably conducive to persistence of larger human communities. Trade exchange intensifies. Location of the neighbour of Brazzaville - Kinshasa, has a similar character. The last of the capital cities listed in the group of those at the intermediate borders, Ulan Bator, grew on the Northern Mongolian Upland as an important station for the caravans crossing the Gobi desert. The movement of caravans was forced by the nature of this vegetation zone. The dry, poor zone allowed the development of towns only in the oases, and maintenance of contact between the sparsely distributed centres was a necessity. The town is located at the feet of the Chentei mountain range, at the border of dry steppe and wooded steppe. The reasons of its development must be sought in the different character of the surrounding areas. Accessibility of water and wood, goods much sought after in the dry steppe, in the more humid wooded steppe, allowed for the growth of this centre.

In the last, third group of the capital towns situated at the border of two distinctly different vegetation zones, a specific role is played by the grassy formations (savannahs, steppes). These are perfect natural grazing areas of a high natural fertility. Steppes and savannahs may sustain many relatively large grazing animals, since grazing of grasses stimulates them to a more abundant growth. This is made use of by humans, especially in the moderate zone, where steppes have become one great cultivated area. The presence of a territory capable of feeding large human centres has definite significance for the location of capitals. On the areas of Africa the herds are moving to follow the precipitation during the rainy season. Almost all the steppes of the moderate zones are used as arable land, both in Eurasia and in the North and South America. Great Prairies, Pampas, or the steppes of Asia, are nowadays the areas supplying enormous quantities of cereals, not only to the neighbouring territories, but also to the whole world. The initial reason for location - the wish of ensuring satisfying food supply - was apparently extended by the motive of trade with food surpluses.

Kishyniev, Ankara, Antananarivo, Dodoma, Luanda, and Canberra are a part of the capitals located on the borders of the distinctly differing zones: the forest and the grassy ones. Kishyniev, situated over a confluent of the Dnester river at the feet of the Kodra hills, lies on the border between the meadow steppe and the deciduous forest. Both of these habitats are characterised by high fertility, and so it is not difficult to conclude that there is a dependence of the location of Kishyniev upon the vegetation zones. The meadow steppes are the most fertile variety of steppes and have by now been turned entirely into the arable land. In the case of Ankara, located in the heartland of the Anatolian Plateau the border between the vegetation zones has high significance, because there are no other important bound- 
aries, whose role in location could be noticeable. Antananarivo was established in the centre of Madagascar, on a hill, over the fertile plain flooded by the river Ikopa. It appears that the river and the hill - where the climatic conditions are more bearable - play in this case a greater role than the vegetation zones. Dodoma was chosen as capital city in view of its central location, but the fact that it is situated at the border between the vegetation zones does not seem to be just a coincidence. Luanda developed as a seaport. The very fact of harbour location does not negate, though, the importance of being situated at the border of the vegetation zones. The presence of the grassy areas of savannah allowed crop production and animal husbandry, also oriented at export, while the proximity of forests ensured sufficient supply of the high quality varieties of wood, successfully exported as well. Canberra was located in the richest of provinces at the border of the climatic zones - the moderate and the subtropical, that is also at the border of vegetation zones. The role of the forest as the tourist and recreational area for the new capital was also taken into consideration.

The subsequent group is constituted by the towns located at the borders between the steppes and the deserts, or semi-deserts. Ashkhabad is a town located in a fertile oasis at the feet of the mountain range Kopet Dag, at the very edge of the Kara-Kum desert. Dushanbe developed in the bowl among the mountains. Bishkek was established in the Chuisk Low at the feet of Kirghiz Mts. Tashkent is located within the foreland of the Tien-shan mountains, in an oasis, in the valley of Chirchik river. Teheran developed in the foreland of the Elbrus mountains. The difference between the steppe and the desert or semi-desert is much more pronounced than for the two forest zones. The possibility of extensive animal raising has been and still is appropriately complementary with the oasis-based agriculture or the extraction of salt, so valuable not only on the areas of the steppes. The capital of Kazakhstan Astana - is situated on the border between the steppes and the semi-deserts. It grew to a large centre of trade in cattle. Salt and dates were also brought from the desert. This indeed is an example of a capital, which owes its development to a large extent to its location on the border of the vegetation zones.

The last subgroup is made up of the capitals located at the border of the Mediterranean vegetation (hard leaved forests and macchii scrub) and semi-deserts. Amman developed on the trade routes between the desert and the coast. Damascus, lying on the hills, is an old oasis on the route of the caravans bringing salt and dates from the desert. The towns of the Middle East were the place of contact between the nomadic peoples (from the desert areas) and the resident population (from the Mediterranean areas). Here the exchange of products of plant origin was taking place (dates from the east for the cereals or citrus fruits from the west), and through here the routes of caravans went. The interface of the two plant formations so different as the Mediterranean vegetation and the desert brought a spontaneous development of towns, resulting in location of numerous capitals on this border. They are located so in spite of the frequently peripheral character 
of these areas (vegetation limits being equivalent to political boundaries) with respect to the remaining desert territories of the respective country.

Although we cannot exclude the boundaries of vegetation zones as the partial reasons of location, in many of the cases here mentioned strong impulses for the development of towns came from factors other than existence of borders between the vegetation zones (surface relief, location between two different large-scale geomorphological units, or seaside location). Borders of vegetation zones had an indirect, but apparently not insignificant influence. Attribution of an important role to the borders between plant complexes in cases of location of all the capitals would of course be a mistake. Thus, the border between two forest zones cannot be attributed a too high weight, since the difference between the two and their complementarity are not significant. On the other hand, much higher importance ought to be attached to the general vegetation borders linked with the third group of capitals here listed. In this case we namely deal with location of capitals between the formations that are distinctly different, where the diversity of economic activities and potentials on the adjacent areas leads to a lively trade exchange, especially in the border zone. The deeper the difference between the two neighbouring territories, the more intensive the exchange phenomenon. The most pronounced role should be attributed to the border between the forest and the steppe areas, whose difference and complementarity are bigger than in the cases of borders between the steppe and the desert, or the Mediterranean vegetation and the desert. The role of all these three types of borders is certainly bigger than that of the borders existing between the more similar plant formations (the first and the second group). We will, of course, never find the examples of capitals, whose location is linked only with the boundary of the plant formations. The boundaries usually have a serious, but mostly indirect influence on location. Likewise, one should not simplify the problem by concluding in a straightforward manner that if a capital is located at the junction of two geomorphological forms, then the difference in vegetation of these two forms, resulting from the surface relief, would not have any more an influence on location. One should try to analyse in each case whether in reality in the process of town location the role of surface relief was superior to that of the character of vegetation.

\section{REFERENCES}

B ea uje u-Garnier J., Chabot G., 1971, Zarys geografii miast [An outline for urban geographyl, PWE, Warszawa.

J a n i s z e w s k i M., 1982, Typologia położenia geograficznego stolic europejskich [Typology of geographical locations of the European capitals], Geografia w Szkole, Warszawa, $35,2,62-67$.

J a n is z ew sk i M., 1983, Typologia położenia geograficznego stolic pozaeuropejskich [Typology of geographical locations of the non-European capitals], Geografia w Szkole, Warszawa, 36, 3, 127-132. 
Pergamon World Atlas, 1968, Warszawa.

$\mathrm{S} t$ a s z e w s k i J., 1957, Ekwidystanty morskie a rozmieszczenie człowieka na kuli ziemskiej w okresie 1850-1940 [Marine equidistances and the distribution of man on the globe in the period 1850-1940], typescript, Sopot.

Wrzosek A., 1976, Rozważania nad położeniem i rozwojem przestrzennym miast nadrzecznych [Considerations of the location and spatial development of the riverside towns], Przeglad Geograficzny, Warszawa, 48, 4, 649-655.

$\mathrm{Zi}$ i rh offer A., 1959, Niektóre zgadnienia rozmieszcenia czlowieka na kuli ziemskiej [Some questions of distribution of man on the globe], Czasopismo Geograficzne, Warszawa, XXX, 4, 393-414. 